\title{
Does Italy represent an opportunity for temporary migrants from the eastern partnership countries?
}

\author{
Sabrina Marchetti ${ }^{1}$, Daniela Piazzalunga ${ }^{2}$ and Alessandra Venturini $i^{{ }^{*}}$
}

\author{
* Correspondence: \\ alessandra.venturini@unito.it \\ ${ }^{3}$ Department of Economics, MPC, \\ European University Institute, \\ University of Turin, IZA and CHILD, \\ Lungo Dora Siena 100, 10153 \\ Torino, Italy \\ Full list of author information is \\ available at the end of the article
}

\begin{abstract}
The paper reviews the dynamics and characteristics of immigrant inflows to Italy from the EU's Eastern Partnership countries. In particular, it compares Ukrainian and Moldovan migrants, which are the most numerous nationalities. Even though both groups show a feminisation of flows, high participation in the labour market and strong involvement in the domestic and care sectors, our research highlights the existence of two different migration profiles. Migration from Ukraine, mostly mature women, is mainly temporary; on the contrary, Moldovans tend to be younger, with a higher share of male and family reunifications and tend to migrate permanently.

JEL codes: J15; J61

Keywords: Migration; Temporary migration; Eastern partnership countries
\end{abstract}

\section{Introduction}

In all the 28 member states of the European Union, the old-age dependency ratio, namely the share of people who are $65+$ in relation to the working age (15-64) population, is increasing. The growth rate is impressive. In the 1950s, $65+$ people accounted for less than $15 \%$ of the working age population, now (2012) they are $27 \%$, and in 2050 they will reach 50\% (Eurostat 2013; European Commission 2012). This tendency has worrying repercussions for the sustainability of the relationship between welfare and labour market for all European societies. Yet, Italy is probably the country with the highest risk, as its dependency ratio is already 32\% (Eurostat 2013). 2.3 million Italians among the 65+ already need health support (Pasquinelli and Rusmini 2013).

An ageing and shrinking population is creating demand for a foreign population not only for temporary foreign migrant workers. However, rising unemployment $-12 \%$ in 2012 according to Istat (2013) - and anti-immigration sentiments among Italians (at least $55 \%$ of citizens consider migration more a problem than an opportunity, Transatlantic Trends 2011) make it difficult to suggest a more open policy. Public opinion is concerned about: competition in the labour market from migrants; the welfare system being overstretched by migrant use; and criminal behaviour resulting from difficult cultural and social integration. Research ${ }^{1}$ shows that migrants are not negatively affecting natives' wage or employment and that, comparatively speaking, they do not benefit from welfare services more than Italians do. Nevertheless, the negative feelings about open migration remain. 
Temporary migration has been offered up as a possible solution. It provides the workforce that Italy needs, due to its population aging, and because of its welfare system, while it is more flexible than permanent migration and it does not carry the same social costs. Therefore, migrants from relatively richer and geographically closer countries are preferred because it is believed that they are more likely to return. This is why migrants from the Eastern Partnership (EaP) countries - Armenia, Azerbaijan, Belarus, Georgia, Moldova and Ukraine - are increasingly an object of interest for Italy.

This paper describes profiles of migrants from EaP countries, in particular from Moldova and Ukraine, which are the most visible and quantitatively the most relevant groups in Italy, using data from the Italian Labour Force Survey (LFS), as well as data on residence permits and other secondary sources. It underlines similarities, but it also highlights differences. These have been too often neglected - considering migrants from Eastern Europe as a whole - while on the contrary differences in characteristics reflect differences in Ukrainian and Moldovan integration on the Italian labour market and in their migratory projects. Their profiles will be discussed in relation to Poles and Romanians who make for a telling point of comparison.

In the following pages, after a general overview of migratory flows from EaP countries to Italy, we are going to provide a specific analysis of labour market outcomes of Ukrainians and Moldovans. In conclusion, we will show how even if migration from the EaP countries concentrates on the flexible domestic and care and construction sectors, EaP migrants engage in different forms of temporary and permanent migration. Ukrainians are made up of a prevalently female and older migrant population, which does not plan to settle. Moldovans, meanwhile, tend to be younger and more gender balanced and they wish to settle, at least for now.

The link between the different migration projects and migration policies is not clear. However, it should be taken into consideration in the articulation of the Mobility Partnership Agreement signed by the EU and the Moldovan Government, which in light of favouring development and also the return of migrants, introduce more temporary migration moves.

\section{Statistical data}

In order to assess the total number of migrants from EaP countries in Italy and their reasons for migration, this paper focuses on Istat data about residence permits, based on the records of the Italian Home Office. Since March 2007 individuals from new EU Member States do not need a residence permit: we do not, then, have information derived from these data for people from Poland and Romania $^{2}$.

We also employ micro-data from the 2011 Istat Labour Force Survey (2nd quarter) and the 2008 Survey (2nd quarter), the second of which contains an ad hoc module for foreign people. The Labour Force Survey is one of the best general datasets available and in particular for labour market outcomes. It does, though, have some drawbacks. The reference population includes all households and their members officially resident in Italy (from population registers). Thus, illegal, seasonal and unregistered immigrants are not included. 
In our analysis of labour market outcomes, the sample selected includes working-age individuals (between 15 and 64 years of age). Workers are classified according to their citizenship.

Secondary sources of data are produced by independent and private Italian research centres that focus on migration. We refer to $\mathrm{CENSIS}^{3}$, which carries out research into social sciences and economics; and to ISMU ${ }^{4}$, a foundation which conducts an annual sample survey on immigrants in Lombardy (together with ORIM ${ }^{5}$ ) and which publishes an annual report on migration to Italy. This information helps to fill some gaps in information that can be derived from Istat micro-data. However, they cannot be used to conduct a comprehensive analysis.

For a complete table on the sources which are available for migration in Italy, with their pros and cons, see also Marchetti et al. (2013, pp. 84-85).

\section{Evolution of EaP migration in Italy}

Inflows from EaP countries began only at the end of the 1990s. They were part of the second wave from the Eastern European countries, which had started after the fall of the Berlin Wall in 1989. The first wave was composed of Albanian and Polish migrants, followed by Ukrainians, Romanians and finally Moldovans, who frequently have Romanian nationality as well. Yet, in the 1990s, the stock of Eastern European migrants in Italy was still very small. It was only with the big regularization of 2002 that the quantity of Eastern European migrants in the country almost doubled, rising 89 per cent (Marchetti et al. 2013). In fact, among the ten nationalities that most profited from this regularisation, five were Eastern European: Romanians (20.4 per cent), Ukrainians (15.2 per cent), Albanians (7.9 per cent), and Poles and Moldovans in smaller proportions. Taken together, these nationalities went to make up 52 per cent of the applications submitted. Equally worth noticing is the fact that these measures were matching demand from industry and from households for foreign workers (Bentivogli et al. 2004).

At present, immigrants from EaP countries account for 10 per cent of the non-EU foreign population in Italy (residence permits data; Marchetti et al. 2013). Ukrainians (6\%) and Moldovans (4\%) by themselves cover this share almost fully, with respectively 218,000 and 142,000 migrants. It is a very small percentage of the total Italian population: immigrants from EaP countries stand at only 1 per cent. Figure 1 shows the evolution in the numbers of residence permit holders from EaP countries. The peaks after 2003 and 2009 (dotted lines) reflect regularisation measures. In fact, without entering into the specific details of Italian migration policies, it is worth noting that there is discontinuity in migration data because of the sudden jumps in those officially present after each regularisation measure ${ }^{6}$.

Ukrainians had previous experience of migration to Germany, following a pattern established by Polish migrants (Zimmerman and Biavaschi 2013). Likewise, they also arrived in Italy following the Polish flow, which had easy access to Italy during the pontificate of Pope John Paul II and the consequent more flexible visa regime between Italy and Poland. As in communist times, Poland and Ukraine have today a kind of free mobility regime, together with strong traditional migrant relationships (Duszczyk et al. $2013)^{7}$. This free regime allows the exchange of information and favours temporary migration plans. 


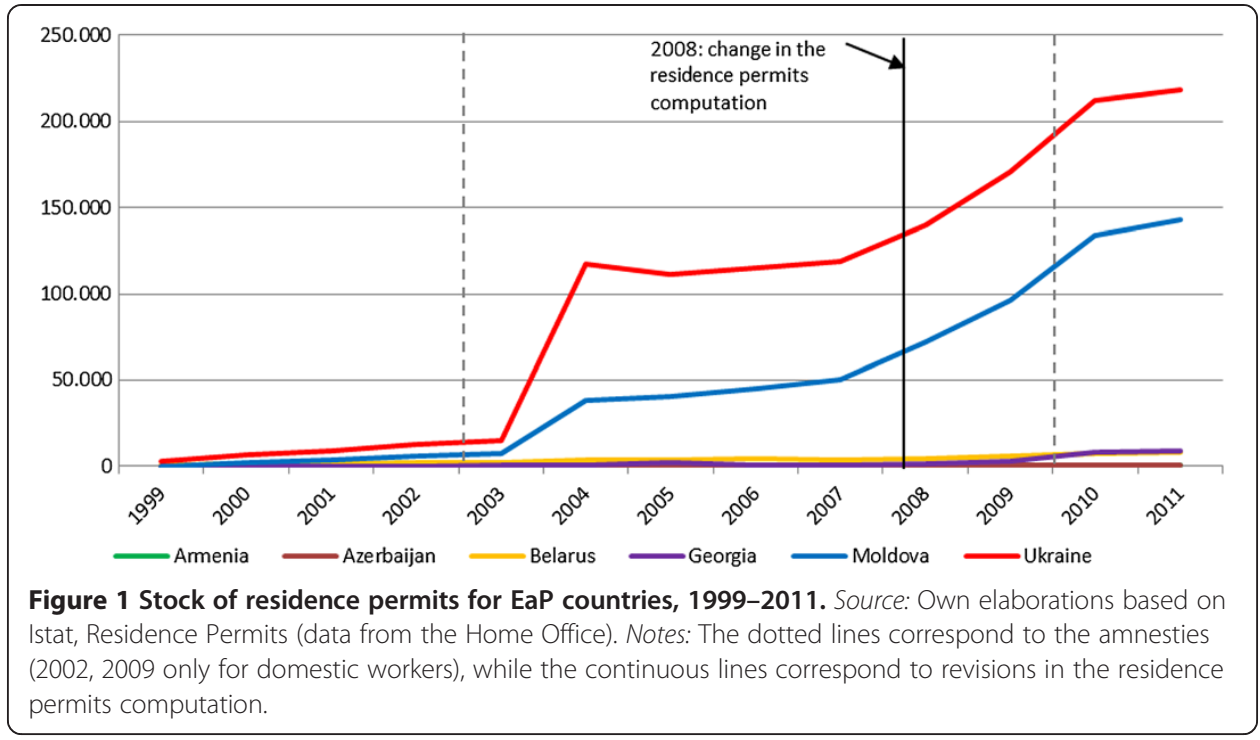

In the case of Moldova and Romania, meanwhile, one can observe a high level of movement between the two countries, which, after all, used to be a single country. This is favoured by the fact that, in the middle of the 2000s, many Moldovans took Romanian nationality in order to benefit from the 2007 EU Enlargement. In this way, they were able to enjoy the same rights to free movement that other EU citizens enjoyed.

The regional distribution of these communities is a strong signal of the contiguity between Moldova and Romania, on the one hand, and Ukraine and Poland, on the other, as the settlement of migrants in particular regions is often ascribed to pre-existing networks (Vianello 2009).

As can be seen from Table 1, while other migrants are mainly concentrated in Northern and Central Italy, a high share of Poles and Ukrainians also live in Southern Italy (24\%), where other communities are almost absent.

Table 1 Regional distribution of total resident population, 2011

\begin{tabular}{lllllll}
\hline & Italians & Total immigrants & Ukraine & Moldova & Poland & Romania \\
\hline Region & & & & & & \\
Nord-west & 0.26 & 0.35 & 0.29 & 0.29 & 0.11 & 0.30 \\
& $(0.00)$ & $(0.01)$ & $(0.03)$ & $(0.03)$ & $(0.02)$ & $(0.01)$ \\
Nord-east & 0.19 & 0.26 & 0.29 & 0.49 & 0.22 & 0.20 \\
& $(0.00)$ & $(0.01)$ & $(0.03)$ & $(0.04)$ & $(0.03)$ & $(0.01)$ \\
Centre & 0.19 & 0.25 & 0.17 & 0.18 & 0.36 & 0.35 \\
& $(0.00)$ & $(0.01)$ & $(0.02)$ & $(0.03)$ & $(0.04)$ & $(0.01)$ \\
South & 0.25 & 0.10 & 0.24 & 0.03 & 0.24 & 0.11 \\
& $(0.00)$ & $(0.00)$ & $(0.02)$ & $(0.01)$ & $(0.03)$ & $(0.01)$ \\
Islands & 0.12 & 0.04 & 0.01 & 0.00 & 0.07 & 0.05 \\
& $(0.00)$ & $(0.00)$ & $(0.00)$ & $(0.00)$ & $(0.02)$ & $(0.01)$ \\
\hline Observations & 152,680 & 10,898 & 460 & 314 & 292 & 2,210 \\
\hline
\end{tabular}

Source: Own elaborations based on Istat LFS 2011 - 2nd quarter. Standard errors in parenthesis. 
This different contiguity is seen in the profiles of Ukrainian and Moldovan migrants in Italy, in particular when we look at their differences and their migration patterns, as shown in Section 5.

\section{Characteristics of EAP migrants: similarities}

The feminisation of flows is the most striking aspect of EaP migration to Italy. Migrants from these countries are, indeed, mainly women: $76 \%$ of Ukrainian migrants and 65\% of Moldovans. This stands in contrast, for example, with migration from Romania where women make up only $54 \%$ of the migrant population and there is a substantial gender balance, while 65\% of Polish migrants are women (see Table 2). The feminisation of the flows is in line with the general increase in female migration, not only for family reunification, but also in cases where women are first movers or come for work, in particular driven by care and domestic work demand.

Indeed, LFS data for 2011 show that labour participation is very high for Eastern European migrants (particularly Moldovans and Ukrainians), standing at 80-81\% in comparison to the $61.2 \%$ of natives and $71.4 \%$ of other migrants (see Table 3 ). Data are even more astonishing for female labour participation, with $78-82 \%$ of Ukrainian and Moldovan women in the labour force compared to $70 \%$ of Polish and Romanian women, 59\% of foreign women and $51 \%$ of native women. This confirms that a high percentage of Moldovan and Ukrainian women migrate to Italy to work.

When we consider sectors of employment, 66\% of Moldovan and 71\% of Ukrainian women are employed in family services, compared with about $50 \%$ of women among other migrants groups and among Romanian and Polish migrants (see Table 4). They, meanwhile, naturally have less significant participation in other jobs, even in comparison to "similar" groups such as Polish and Romanian migrants.

Censis (2010) reports that 2.5 million Italian families hire a domestic worker or a caregiver, giving employment to about 1.5 million people. Those employed are, for the most part, women but, increasingly, there are also men (on the masculinisation of domestic work in Italy see Ambrosini and Beccalli 2009).

The reason behind this expansion is rooted in the aging Italian population and in the traditional weakness of welfare in Italy, where families are the main providers of everyday care services to children, the elderly, the disabled and other needy people. It places Italy as one of the "Mediterranean welfare" countries together with Spain, Greece and Portugal (Esping-Andersen 1990; Ferrera and Rhodes 2000). In this scenario the crisis of traditional family models, the rapid ageing of society, and other life-style transformations have pushed increasing numbers of households to search for external help for tasks which were accomplished within the family itself in the not

Table 2 Gender composition of total resident population, 2011

\begin{tabular}{lllllll}
\hline & Italians & Total immigrants & Ukraine & Moldova & Poland & Romania \\
\hline Women & 0.51 & 0.52 & 0.76 & 0.64 & 0.65 & 0.54 \\
& $(0.00)$ & $(0.01)$ & $(0.03)$ & $(0.03)$ & $(0.04)$ & $(0.01)$ \\
\hline Observations & 152,680 & 10,898 & 460 & 314 & 292 & 2,210 \\
\hline
\end{tabular}

Source: Own elaborations based on Istat LFS 2011 - 2nd quarter. Standard errors in parenthesis. 
Table 3 Employment status, working age population (15-64), 2008 and 2011

\begin{tabular}{|c|c|c|c|c|c|c|c|}
\hline & & \multicolumn{3}{|c|}{2008} & \multicolumn{3}{|c|}{2011} \\
\hline & & $\bar{F}$ & $M$ & Tot & $\bar{F}$ & $M$ & Tot \\
\hline \multirow[t]{4}{*}{ Italians } & Labour force & 51.5 & 74.2 & 62.9 & 50.6 & 71.9 & 61.2 \\
\hline & Employment rate & 47.2 & 70.2 & 59.0 & 46.3 & 66.9 & 56.6 \\
\hline & Unemployment rate & 8.4 & 5.4 & 6.7 & 8.4 & 6.9 & 7.5 \\
\hline & Observations & 51,998 & 50,355 & 102,353 & 46,741 & 44,660 & 91,401 \\
\hline \multirow[t]{4}{*}{ Total immigrants } & Labour force & 59.7 & 85.6 & 72.3 & 59.3 & 84.7 & 71.4 \\
\hline & Employment rate & 52.1 & 80.4 & 65.9 & 50.9 & 77.5 & 63.5 \\
\hline & Unemployment rate & 12.7 & 6.0 & 8.9 & 14.2 & 8.5 & 11.0 \\
\hline & Observations & 2,272 & 1,981 & 4,253 & 4,488 & 3,821 & 8,309 \\
\hline \multirow[t]{4}{*}{ Ukraine } & Labour force & 76.6 & 78.9 & 77.0 & 82.1 & 78.6 & 81.4 \\
\hline & Employment rate & 70.4 & 77.6 & 71.7 & 77.0 & 73.7 & 76.3 \\
\hline & Unemployment rate & 8.1 & 1.7 & 6.9 & 6.3 & 6.3 & 6.3 \\
\hline & Observations & 136 & 30 & 166 & 327 & 83 & 410 \\
\hline \multirow[t]{4}{*}{ Moldova } & Labour force & 77.4 & 87.4 & 79.9 & 77.6 & 84.0 & 79.8 \\
\hline & Employment rate & 67.7 & 87.4 & 72.8 & 70.9 & 72.2 & 71.4 \\
\hline & Unemployment rate & 12.4 & 0.0 & 8.9 & 8.6 & 14.1 & 10.6 \\
\hline & Observations & 72 & 24 & 96 & 174 & 91 & 265 \\
\hline \multirow[t]{4}{*}{ Poland } & Labour force & 58.8 & 91.1 & 65.3 & 71.0 & 89.4 & 76.9 \\
\hline & Employment rate & 54.8 & 87.3 & 61.4 & 66.2 & 78.4 & 70.1 \\
\hline & Unemployment rate & 6.7 & 4.2 & 6.0 & 6.8 & 12.2 & 8.9 \\
\hline & Observations & 100 & 24 & 124 & 175 & 80 & 255 \\
\hline \multirow[t]{4}{*}{ Romania } & Labour force & 65.0 & 84.7 & 74.6 & 68.8 & 88.2 & 77.7 \\
\hline & Employment rate & 57.6 & 79.9 & 68.5 & 59.1 & 81.3 & 69.3 \\
\hline & Unemployment rate & 11.3 & 5.7 & 8.2 & 14.2 & 7.8 & 10.8 \\
\hline & Observations & 364 & 305 & 669 & 1,022 & 786 & 1,808 \\
\hline
\end{tabular}

Source: Own elaborations based on Istat LFS 2011 - 2nd quarter and on Istat LFS 2008 - 2nd quarter.

too distant past (Del Boca and Venturini 2014). This type of work not only provides what is called "second welfare" (family welfare) for the elderly; but it also favours women's participation in the labour market by allowing highly-skilled women to work longer hours (Barone and Mocetti 2012) saving them too from having to retire earlier to take care of elderly parents (Romiti and Rossi 2011). Thus, this "second welfare" system supports the actual welfare system and boosts the labour supply of native women.

Interestingly, work in the family sector is not uniform.

There are at least three different forms of employment: first of all, the "live-in" position in which the worker lives in the same house of the employer, i.e. the family or the old person who is under his or her care. Secondly, there is the "live-out" worker, who has still only one employer but enters his/her house in the morning and leaves it in the evening. Lastly, there is a more "multi-employer" modality for which the worker is in different houses day by day and is paid on an hourly basis by different employers. The first type of job is incompatible with a personal family life in the country of destination: native women rarely compete for these types of jobs but demand is much higher because the ageing population and the increase in women's labour force participation increase the need for family support. Those who want to 
Table 4 Sectors of employment, working-age population (15-64), 2011

\begin{tabular}{|c|c|c|c|c|c|c|c|c|c|c|c|c|}
\hline & \multicolumn{2}{|l|}{ Italians } & \multicolumn{2}{|c|}{$\begin{array}{l}\text { Total } \\
\text { immigrants }\end{array}$} & \multicolumn{2}{|c|}{ Ukraine } & \multicolumn{2}{|c|}{ Moldova } & \multicolumn{2}{|c|}{ Poland } & \multicolumn{2}{|c|}{ Romania } \\
\hline & $M$ & $F$ & $M$ & $F$ & $M$ & $\mathrm{~F}$ & $M$ & $\mathrm{~F}$ & $M$ & $F$ & $M$ & $\mathrm{~F}$ \\
\hline \multirow[t]{2}{*}{ Agriculture } & 0.04 & 0.03 & 0.06 & 0.02 & 0.03 & 0.02 & 0.06 & 0.00 & 0.02 & 0.02 & 0.07 & 0.04 \\
\hline & $(0.00)$ & $(0.00)$ & $(0.01)$ & $(0.00)$ & $(0.02)$ & $(0.01)$ & $(0.03)$ & $(0.00)$ & $(0.01)$ & $(0.01)$ & $(0.01)$ & $(0.01)$ \\
\hline \multirow[t]{2}{*}{ Industry } & 0.25 & 0.13 & 0.28 & 0.09 & 0.22 & 0.04 & 0.29 & 0.04 & 0.37 & 0.02 & 0.18 & 0.09 \\
\hline & $(0.00)$ & $(0.00)$ & $(0.01)$ & $(0.01)$ & $(0.07)$ & $(0.01)$ & $(0.08)$ & $(0.02)$ & $(0.08)$ & $(0.01)$ & $(0.02)$ & $(0.01)$ \\
\hline \multirow[t]{2}{*}{ Construction } & 0.12 & 0.02 & 0.27 & 0.00 & 0.28 & 0.00 & 0.32 & 0.00 & 0.35 & 0.00 & 0.46 & 0.01 \\
\hline & $(0.00)$ & $(0.00)$ & $(0.01)$ & $(0.00)$ & $(0.08)$ & $(0.00)$ & $(0.07)$ & $(0.00)$ & $(0.08)$ & $(0.00)$ & $(0.03)$ & $(0.00)$ \\
\hline \multirow{2}{*}{$\begin{array}{l}\text { Commerce, hotels and } \\
\text { restaurants. }\end{array}$} & 0.29 & 0.25 & 0.27 & 0.19 & 0.31 & 0.11 & 0.24 & 0.15 & 0.12 & 0.25 & 0.21 & 0.19 \\
\hline & $(0.00)$ & $(0.00)$ & $(0.01)$ & $(0.01)$ & $(0.08)$ & $(0.02)$ & $(0.07)$ & $(0.04)$ & $(0.04)$ & $(0.05)$ & $(0.21)$ & $(0.02)$ \\
\hline \multirow{2}{*}{$\begin{array}{l}\text { Business and support } \\
\text { services }\end{array}$} & 0.12 & 0.16 & 0.05 & 0.09 & 0.03 & 0.06 & 0.01 & 0.10 & 0.01 & 0.06 & 0.03 & 0.05 \\
\hline & $(0.00)$ & $(0.00)$ & $(0.01)$ & $(0.01)$ & $(0.02)$ & $(0.02)$ & $(0.01)$ & $(0.04)$ & $(0.01)$ & $(0.04)$ & $(0.01)$ & $(0.01)$ \\
\hline \multirow{2}{*}{$\begin{array}{l}\text { Public and social } \\
\text { services }\end{array}$} & 0.15 & 0.33 & 0.02 & 0.10 & 0.00 & 0.07 & 0.02 & 0.04 & 0.01 & 0.17 & 0.01 & 0.10 \\
\hline & $(0.00)$ & $(0.00)$ & $(0.00)$ & $(0.01)$ & $(0.00)$ & $(0.02)$ & $(0.02)$ & $(0.02)$ & $(0.01)$ & $(0.04)$ & $(0.01)$ & $(0.02)$ \\
\hline \multirow{2}{*}{$\begin{array}{l}\text { Other social, family } \\
\text { services }\end{array}$} & 0.04 & 0.08 & 0.06 & 0.50 & 0.12 & 0.71 & 0.06 & 0.66 & 0.12 & 0.49 & 0.03 & 0.52 \\
\hline & $(0.00)$ & $(0.00)$ & $(0.01)$ & $(0.01)$ & $(0.06)$ & $(0.04)$ & $(0.03)$ & $(0.05)$ & $(0.05)$ & $(0.06)$ & $(0.01)$ & $(0.03)$ \\
\hline Observations & 29,006 & 20,918 & 2,882 & 2,183 & 60 & 248 & 62 & 121 & 62 & 118 & 618 & 588 \\
\hline
\end{tabular}

settle in the country and then reunify with their family tend to do this work only at the beginning of their life in Italy. Alternatively, the first kind of job can last a few years, as part of a temporary migration project. In conclusion, these are three very distinct types of jobs. They belong, of course, to the same sector, but they involve very different migration patterns.

According to Ismu data (2011a), in Lombardy migrants from Ukraine are the most likely to live in the workplace (37\%), hence to be employed in the care sector as "live-in" workers, followed by Moldovans (26\%), while Romanians living in the workplace are only $6 \%{ }^{8}$. These figures are probably true over the rest of the country, as Lombardy is the one of the regions with the highest percentage of migrants (see Marchetti et al. 2013).

In Italy, under-occupation or over-education is common among both migrants and natives, but it is more pronounced among eastern migrants because their average level of education is higher (see Table 5 and Table 6).

Under-occupation is even stronger among females. The share of tertiary educated male and female is larger amongst Italian than in the total migrant group and their number among Ukrainian women is the biggest. $26 \%$ of Ukrainian women hold a tertiary degree, compared to $15 \%$ of Moldovan women, and about $10 \%$ of Romanian and Polish female migrants (see Table 7). Yet, regardless of their level of education, migrants from Ukraine and Moldova accept unskilled and low skilled jobs in the family and construction sectors, where all migrants are concentrated (see Table 8). These sectors present high turnover rates and are also compatible with temporary migration patterns. 
Table 5 Skill mismatch by gender, working age population (15-64), 2011

\begin{tabular}{|c|c|c|c|c|c|c|c|c|c|c|c|}
\hline & \multirow[t]{3}{*}{ Professions } & \multicolumn{5}{|c|}{ Education } & \multicolumn{5}{|c|}{ Education } \\
\hline & & Primary - below & Lower sec. & Upper sec. & Tertiary & Tot. & Primary - below & Lower sec. & Upper sec. & Tertiary & Tot \\
\hline & & \multicolumn{5}{|c|}{ Male } & \multicolumn{5}{|c|}{ Female } \\
\hline \multirow[t]{5}{*}{ Moldova } & Unskilled & 0.00 & 0.07 & 0.06 & 0.02 & 0.14 & 0.00 & 0.20 & 0.22 & 0.14 & 0.56 \\
\hline & Low skilled & 0.00 & 0.19 & 0.43 & 0.18 & 0.80 & 0.04 & 0.14 & 0.22 & 0.05 & 0.44 \\
\hline & Skilled & 0.00 & 0.00 & 0.01 & 0.03 & 0.04 & 0.00 & 0.00 & 0.00 & 0.00 & 0.00 \\
\hline & Highly skill & 0.00 & 0.00 & 0.02 & 0.00 & 0.02 & 0.00 & 0.00 & 0.00 & 0.00 & 0.00 \\
\hline & Total & 0.00 & 0.26 & 0.52 & 0.23 & 1.00 & 0.04 & 0.34 & 0.44 & 0.19 & 1.00 \\
\hline \multirow[t]{5}{*}{ Ukraine } & Unskilled & 0.04 & 0.05 & 0.12 & 0.00 & 0.21 & 0.01 & 0.07 & 0.18 & 0.13 & 0.40 \\
\hline & Low skilled & 0.02 & 0.21 & 0.45 & 0.08 & 0.77 & 0.03 & 0.13 & 0.27 & 0.14 & 0.57 \\
\hline & Skilled & 0.00 & 0.00 & 0.02 & 0.00 & 0.02 & 0.00 & 0.00 & 0.01 & 0.01 & 0.01 \\
\hline & Highly skill & 0.00 & 0.00 & 0.00 & 0.00 & 0.00 & 0.00 & 0.00 & 0.00 & 0.01 & 0.02 \\
\hline & Total & 0.06 & 0.26 & 0.59 & 0.09 & 1.00 & 0.04 & 0.21 & 0.45 & 0.30 & 1.00 \\
\hline \multirow[t]{5}{*}{ Total immigrants } & Unskilled & 0.05 & 0.10 & 0.09 & 0.01 & 0.24 & 0.04 & 0.14 & 0.21 & 0.04 & 0.43 \\
\hline & Low skilled & 0.07 & 0.27 & 0.33 & 0.03 & 0.71 & 0.04 & 0.14 & 0.25 & 0.05 & 0.48 \\
\hline & Skilled & 0.00 & 0.00 & 0.01 & 0.01 & 0.03 & 0.00 & 0.00 & 0.02 & 0.03 & 0.05 \\
\hline & Highly skill & 0.00 & 0.00 & 0.00 & 0.02 & 0.02 & 0.00 & 0.00 & 0.01 & 0.02 & 0.03 \\
\hline & Total & 0.12 & 0.37 & 0.43 & 0.08 & 1.00 & 0.08 & 0.28 & 0.49 & 0.15 & 1.00 \\
\hline
\end{tabular}

Source: Own elaborations based on Istat LFS, 2011, 2nd quarter.

Notes: $\mathrm{n}^{\circ}$ of observations: Moldova 62 men, 121 women; Ukraine 60 men, 248 women; total immigrants 2,882 men, 2,183 women. 
Table 6 Skill mismatch by gender, working age population (15-64), 2011

\begin{tabular}{|c|c|c|c|c|c|c|c|c|c|c|c|}
\hline & \multirow[t]{3}{*}{ Professions } & \multicolumn{5}{|c|}{ Education } & \multicolumn{5}{|c|}{ Education } \\
\hline & & Primary - below & Lower sec. & Upper sec. & Tertiary & Tot. & Primary - below & Lower sec. & Upper sec. & Tertiary & Tot. \\
\hline & & \multicolumn{5}{|c|}{ Male } & \multicolumn{5}{|c|}{ Female } \\
\hline \multirow[t]{5}{*}{ Poland } & Unskilled & 0.04 & 0.07 & 0.12 & 0.02 & 0.25 & 0.03 & 0.04 & 0.23 & 0.00 & 0.30 \\
\hline & Low skilled & 0.00 & 0.22 & 0.42 & 0.03 & 0.67 & 0.01 & 0.07 & 0.44 & 0.07 & 0.59 \\
\hline & Skilled & 0.00 & 0.00 & 0.00 & 0.03 & 0.03 & 0.00 & 0.00 & 0.06 & 0.04 & 0.11 \\
\hline & Highly skill & 0.00 & 0.00 & 0.00 & 0.04 & 0.04 & 0.00 & 0.00 & 0.00 & 0.00 & 0.00 \\
\hline & Total & 0.04 & 0.29 & 0.54 & 0.13 & 1.00 & 0.04 & 0.12 & 0.73 & 0.11 & 1.00 \\
\hline \multirow[t]{5}{*}{ Romania } & Unskilled & 0.02 & 0.06 & 0.11 & 0.00 & 0.19 & 0.02 & 0.10 & 0.30 & 0.02 & 0.45 \\
\hline & Low skilled & 0.03 & 0.21 & 0.54 & 0.01 & 0.79 & 0.02 & 0.11 & 0.33 & 0.03 & 0.49 \\
\hline & Skilled & 0.00 & 0.00 & 0.01 & 0.01 & 0.01 & 0.00 & 0.00 & 0.02 & 0.03 & 0.06 \\
\hline & Highly skill & 0.00 & 0.00 & 0.00 & 0.00 & 0.00 & 0.00 & 0.00 & 0.00 & 0.01 & 0.01 \\
\hline & Total & 0.05 & 0.26 & 0.66 & 0.02 & 1.00 & 0.04 & 0.22 & 0.65 & 0.09 & 1.00 \\
\hline \multirow[t]{5}{*}{ Italians } & Unskilled & 0.01 & 0.04 & 0.03 & 0.00 & 0.09 & 0.01 & 0.05 & 0.02 & 0.00 & 0.08 \\
\hline & Low skilled & 0.03 & 0.27 & 0.25 & 0.02 & 0.57 & 0.02 & 0.17 & 0.28 & 0.04 & 0.51 \\
\hline & Skilled & 0.00 & 0.02 & 0.14 & 0.04 & 0.20 & 0.00 & 0.01 & 0.12 & 0.06 & 0.20 \\
\hline & Highly skill & 0.00 & 0.01 & 0.04 & 0.09 & 0.14 & 0.00 & 0.00 & 0.07 & 0.13 & 0.21 \\
\hline & Total & 0.05 & 0.35 & 0.45 & 0.15 & 1.00 & 0.03 & 0.23 & 0.50 & 0.24 & 1.00 \\
\hline
\end{tabular}

Source: Own elaborations based on Istat LFS, 2011, 2nd quarter.

Notes: $n^{\circ}$ of observations: Poland 62 men, 118 women; Romania 618 men, 588 women, Italians 29,006 men, 29,918 women. 
Table 7 Level of education (ISCED), working-age population (15-64), 2011

\begin{tabular}{|c|c|c|c|c|c|c|c|c|c|c|c|c|}
\hline & \multicolumn{2}{|c|}{ Italians } & \multicolumn{2}{|c|}{$\begin{array}{l}\text { Total } \\
\text { immigrants }\end{array}$} & \multicolumn{2}{|c|}{ Ukraine } & \multicolumn{2}{|c|}{ Moldova } & \multicolumn{2}{|c|}{ Poland } & \multicolumn{2}{|c|}{ Romania } \\
\hline & $\bar{M}$ & $F$ & $\bar{M}$ & $F$ & $\bar{M}$ & $\mathrm{~F}$ & $\bar{M}$ & $F$ & $\bar{M}$ & $F$ & $M$ & $F$ \\
\hline \multirow[t]{2}{*}{ Primary and below } & 0.07 & 0.11 & 0.12 & 0.11 & 0.07 & 0.05 & 0.00 & 0.04 & 0.04 & 0.06 & 0.06 & 0.06 \\
\hline & $(0.00)$ & $(0.00)$ & $(0.01)$ & $(0.01)$ & $(0.03)$ & $(0.01)$ & $(0.00)$ & $(0.02)$ & $(0.02)$ & $(0.02)$ & $(0.01)$ & $(0.01)$ \\
\hline \multirow[t]{2}{*}{ Lower secondary } & 0.39 & 0.34 & 0.41 & 0.34 & 0.36 & 0.24 & 0.38 & 0.38 & 0.28 & 0.12 & 0.30 & 0.25 \\
\hline & $(0.00)$ & $(0.00)$ & $(0.01)$ & $(0.01)$ & $(0.07)$ & $(0.03)$ & $(0.06)$ & $(0.05)$ & $(0.07)$ & $(0.03)$ & $(0.02)$ & $(0.02)$ \\
\hline \multirow[t]{2}{*}{ Upper secondary } & 0.41 & 0.40 & 0.41 & 0.43 & 0.51 & 0.45 & 0.45 & 0.44 & 0.58 & 0.69 & 0.62 & 0.61 \\
\hline & $(0.00)$ & $(0.00)$ & $(0.01)$ & $(0.01)$ & $(0.07)$ & $(0.03)$ & $(0.07)$ & $(0.05)$ & $(0.07)$ & $(0.04)$ & $(0.02)$ & $(0.02)$ \\
\hline \multirow[t]{2}{*}{ Tertiary } & 0.12 & 0.15 & 0.07 & 0.12 & 0.06 & 0.26 & 0.17 & 0.15 & 0.10 & 0.12 & 0.02 & 0.08 \\
\hline & $(0.00)$ & $(0.00)$ & $(0.01)$ & $(0.01)$ & $(0.03)$ & $(0.03)$ & $(0.05)$ & $(0.04)$ & $(0.03)$ & $(0.03)$ & $(0.01)$ & $(0.01)$ \\
\hline the & 44,660 & 46,741 & 3,821 & 4,488 & 83 & 327 & 91 & 174 & 80 & 175 & 786 & 1,022 \\
\hline
\end{tabular}

Source: Own elaborations based on Istat, Labour Force Survey (LFS) 2011, 2nd quarter.

Standard errors in parenthesis.

Notes: "Primary and below" corresponds to ISCED 0 and ISCED 1, "lower secondary" corresponds to ISCED 2, "upper secondary" corresponds to ISCED 3 and ISCED 4, "Tertiary" corresponds to ISCED 5 and ISCED 6.

\section{Characteristics of EAP migrants: differences}

Two main differences emerge on the migration pattern of Ukrainians and Moldovans: gender composition and age structure. Even though women make up the majority in both groups, they account for $76 \%$ of Ukrainian migrants, and "only" $64 \%$ of Moldovans (see Table 2). This means that steady numbers of Moldovan men are migrating to Italy (mainly to work in the construction sector, see Table 4). It also suggests that Moldovan

Table 8 Type of occupation (ISCO), working-age population (15-64), 2011

\begin{tabular}{|c|c|c|c|c|c|c|c|c|c|c|c|c|}
\hline & \multicolumn{2}{|c|}{ Italians } & \multicolumn{2}{|c|}{$\begin{array}{l}\text { Total } \\
\text { immigrants }\end{array}$} & \multicolumn{2}{|c|}{ Ukraine } & \multicolumn{2}{|c|}{ Moldova } & \multicolumn{2}{|c|}{ Poland } & \multicolumn{2}{|c|}{ Romania } \\
\hline & $\bar{M}$ & $F$ & $M$ & $\mathbf{F}$ & $M$ & $F$ & $\bar{M}$ & $F$ & $\bar{M}$ & $\mathbf{F}$ & $\bar{M}$ & $F$ \\
\hline \multirow[t]{2}{*}{ Managers, legislators } & 0.04 & 0.02 & 0.01 & 0.00 & 0.00 & 0.00 & 0.02 & 0.00 & 0.00 & 0.00 & 0.00 & 0.00 \\
\hline & $(0.00)$ & $(0.00)$ & $(0.00)$ & $(0.00)$ & $(0.00)$ & $(0.00)$ & $(0.02)$ & $(0.00)$ & $(0.00)$ & $(0.00)$ & $(0.00)$ & $(0.00)$ \\
\hline \multirow[t]{2}{*}{ Professionals } & 0.10 & 0.19 & 0.02 & 0.03 & 0.00 & 0.01 & 0.00 & 0.00 & 0.04 & 0.00 & 0.00 & 0.01 \\
\hline & $(0.00)$ & $(0.00)$ & $(0.00)$ & $(0.00)$ & $(0.00)$ & $(0.01)$ & $(0.00)$ & $(0.00)$ & $(0.03)$ & $(0.00)$ & $(0.00)$ & $(0.00)$ \\
\hline \multirow[t]{2}{*}{ Technicians } & 0.20 & 0.20 & 0.03 & 0.05 & 0.02 & 0.01 & 0.04 & 0.00 & 0.03 & 0.11 & 0.01 & 0.06 \\
\hline & $(0.00)$ & $(0.00)$ & $(0.00)$ & $(0.01)$ & $(0.02)$ & $(0.01)$ & $(0.03)$ & $(0.00)$ & $(0.02)$ & $(0.03)$ & $(0.01)$ & $(0.01)$ \\
\hline \multirow[t]{2}{*}{ Clerks } & 0.08 & 0.20 & 0.01 & 0.03 & 0.00 & 0.00 & 0.04 & 0.02 & 0.00 & 0.02 & 0.00 & 0.02 \\
\hline & $(0.00)$ & $(0.00)$ & $(0.00)$ & $(0.00)$ & $(0.00)$ & $(0.00)$ & $(0.03)$ & $(0.01)$ & $(0.00)$ & $(0.01)$ & $(0.00)$ & $(0.01)$ \\
\hline \multirow{2}{*}{$\begin{array}{l}\text { Service and sales } \\
\text { workers }\end{array}$} & 0.13 & 0.22 & 0.10 & 0.34 & 0.09 & 0.50 & 0.06 & 0.32 & 0.08 & 0.52 & 0.07 & 0.36 \\
\hline & $(0.00)$ & $(0.00)$ & $(0.01)$ & $(0.01)$ & $(0.04)$ & $(0.04)$ & $(0.03)$ & $(0.05)$ & $(0.06)$ & $(0.06)$ & $(0.01)$ & $(0.02)$ \\
\hline \multirow[t]{2}{*}{ Skilled workers } & 0.25 & 0.05 & 0.42 & 0.07 & 0.51 & 0.05 & 0.58 & 0.07 & 0.53 & 0.06 & 0.55 & 0.06 \\
\hline & $(0.00)$ & $(0.00)$ & $(0.01)$ & $(0.01)$ & $(0.09)$ & $(0.02)$ & $(0.08)$ & $(0.03)$ & $(0.08)$ & $(0.04)$ & $(0.02)$ & $(0.01)$ \\
\hline \multirow[t]{2}{*}{ Operators } & 0.11 & 0.03 & 0.17 & 0.04 & 0.17 & 0.02 & 0.12 & 0.03 & 0.07 & 0.00 & 0.17 & 0.05 \\
\hline & $(0.00)$ & $(0.00)$ & $(0.01)$ & $(0.01)$ & $(0.06)$ & $(0.01)$ & $(0.05)$ & $(0.01)$ & $(0.03)$ & $(0.00)$ & $(0.02)$ & $(0.01)$ \\
\hline \multirow[t]{2}{*}{ Elementary occupations } & 0.07 & 0.08 & 0.24 & 0.43 & 0.21 & 0.40 & 0.14 & 0.56 & 0.25 & 0.30 & 0.19 & 0.45 \\
\hline & $(0.00)$ & $(0.00)$ & $(0.01)$ & $(0.01)$ & $(0.07)$ & $(0.04)$ & $(0.05)$ & $(0.06)$ & $(0.07)$ & $(0.05)$ & $(0.02)$ & $(0.03)$ \\
\hline Observations & 29,006 & 20,918 & 2,882 & 2,183 & 60 & 248 & 62 & 121 & 62 & 118 & 618 & 588 \\
\hline
\end{tabular}

Source: Own elaborations based on Istat, Labour Force Survey (LFS) 2011, 2nd quarter.

Standard errors in parenthesis. 
women are more likely to come to Italy to unite with their families than Ukrainians. This is confirmed by data from Ismu (2011a) that show how almost 51\% of migrants from Moldova intend to ask for family reunification, if the partner is still abroad, while for Ukrainians only $18 \%$ have the same intention. This difference must be understood as part of a stronger propensity to permanently migrate amongst Moldovans.

Second, Moldovans are much younger than Ukrainians: $29 \%$ of Ukrainians are in the 45-54 age group, while $32 \%$ of Moldovans are in the $25-34$ one (see Table 9). The data about Ukrainians strikingly contradicts the general trend amongst migrants, who usually are much younger than Italians. Indeed, if we look at the cumulative distribution, while only $50 \%$ of Italians are younger than 45 , this percentage reaches $80 \%$ among all migrants, and $87 \%$ for Romanians, who are the youngest among the groups covered here. Ukrainians are the oldest (only $60 \%$ younger than 45 ), with a value closer to natives than to other foreign nationals. In line with our analysis, which points towards a contiguity between Polish and Ukrainian migration, on the one hand, and between Moldovan and Romanian on the other, migrants from Poland are older than both Romanians and Moldovans, and older than the average migrant (74\% younger than 45 ). Still the share of young Ukrainians is impressively low.

From the point of view of the labour market, this corresponds to the strong presence of mature women, amongst Ukrainians, who are willing to take up jobs as "live-in"

Table 9 Age and years since migration of resident population, 2011

\begin{tabular}{|c|c|c|c|c|c|c|c|c|c|c|c|c|}
\hline & \multicolumn{2}{|c|}{ Italians } & \multicolumn{2}{|c|}{$\begin{array}{c}\text { Total } \\
\text { immigrants }\end{array}$} & \multicolumn{2}{|c|}{ Ukraine } & \multicolumn{2}{|c|}{ Moldova } & \multicolumn{2}{|c|}{ Poland } & \multicolumn{2}{|c|}{ Romania } \\
\hline & & Cum. & & Cum. & & Cum. & & Cum. & & Cum. & & Cum. \\
\hline \multicolumn{13}{|l|}{ Age } \\
\hline \multirow[t]{2}{*}{$0-14$} & 0.14 & 0.14 & 0.20 & 0.20 & 0.11 & 0.11 & 0.16 & 0.16 & 0.13 & 0.13 & 0.17 & 0.17 \\
\hline & $(0.00)$ & & $(0.00)$ & & $(0.02)$ & & $(0.03)$ & & $(0.03)$ & & $(0.01)$ & \\
\hline \multirow[t]{2}{*}{$15-24$} & 0.10 & 0.24 & 0.12 & 0.32 & 0.08 & 0.19 & 0.13 & 0.29 & 0.06 & 0.20 & 0.12 & 0.30 \\
\hline & $(0.00)$ & & $(0.00)$ & & $(0.02)$ & & $(0.02)$ & & $(0.02)$ & & $(0.01)$ & \\
\hline \multirow[t]{2}{*}{$25-34$} & 0.11 & 0.35 & 0.24 & 0.56 & 0.19 & 0.38 & 0.32 & 0.61 & 0.30 & 0.50 & 0.31 & 0.61 \\
\hline & $(0.00)$ & & $(0.01)$ & & $(0.02)$ & & $(0.04)$ & & $(0.03)$ & & $(0.01)$ & \\
\hline \multirow[t]{2}{*}{$35-44$} & 0.15 & 0.50 & 0.24 & 0.80 & 0.22 & 0.60 & 0.18 & 0.79 & 0.24 & 0.74 & 0.27 & 0.87 \\
\hline & $(0.00)$ & & $(0.01)$ & & $(0.02)$ & & $(0.03)$ & & $(0.03)$ & & $(0.01)$ & \\
\hline \multirow[t]{2}{*}{$45-54$} & 0.15 & 0.65 & 0.14 & 0.94 & 0.29 & 0.89 & 0.17 & 0.96 & 0.17 & 0.91 & 0.10 & 0.97 \\
\hline & $(0.00)$ & & $(0.00)$ & & $(0.03)$ & & $(0.02)$ & & $(0.03)$ & & $(0.01)$ & \\
\hline \multirow[t]{2}{*}{$55-64$} & 0.13 & 0.78 & 0.04 & 0.98 & 0.09 & 0.98 & 0.04 & 1.00 & 0.09 & 1.00 & 0.02 & 1.00 \\
\hline & $(0.00)$ & & $(0.00)$ & & $(0.01)$ & & $(0.01)$ & & $(0.03)$ & & $(0.00)$ & \\
\hline \multirow[t]{2}{*}{$65-75$} & 0.11 & 0.89 & 0.01 & 0.99 & 0.02 & 1.00 & 0.00 & 1.00 & 0.00 & 1.00 & 0.00 & 1.00 \\
\hline & $(0.00)$ & & $(0.00)$ & & $(0.01)$ & & $(0.00)$ & & $(0.00)$ & & $(0.00)$ & \\
\hline \multirow[t]{2}{*}{75 and more } & 0.11 & 1.00 & 0.01 & 1.00 & 0.00 & 1.00 & 0.00 & 1.00 & 0.00 & 1.00 & 0.00 & 1.00 \\
\hline & $(0.00)$ & & $(0.00)$ & & $(0.00)$ & & $(0.00)$ & & $(0.00)$ & & $(0.00)$ & \\
\hline \multirow[t]{2}{*}{ Years since migration } & & & 9.76 & & 8.02 & & 6.96 & & 9.61 & & 7.37 & \\
\hline & & & $(0.08)$ & & $(0.22)$ & & $(0.27)$ & & $(0.39)$ & & $(0.10)$ & \\
\hline Observations & 152,68 & & 10,898 & & 460 & & 314 & & 292 & & 2,210 & \\
\hline
\end{tabular}

Source: Own elaborations based on Istat LFS 2011 - 2nd quarter.

Standard errors in parenthesis.

The number of observations for the length of stay is smaller: total immigrants 9,183, Ukraine 439, Moldova 292, Poland 266, Romania 1,991. 
workers (or as "live-out" workers with one employer) and to perform home-care work for their stay in Italy. These women represent a very specific labour force. Having passed their reproductive years, they find themselves at home without a paid job and taking care of their adult children and, eventually, their grandchildren. Temporary labour migration to Italy, in the home-care sector, represents for them the option of supporting their families economically, through remittances and investments through earnings, rather than through their physical presence, waiting for retirement (cfr. Marchetti and Venturini 2013). The contribution of these women is often essential in paying for the higher education of younger Ukrainians.

Moldovans offer a different example. Their migration towards Italy started later than the Ukrainians, as data on "years since migration" show (see Table 9 above). At first, they had the same migratory pattern as Ukrainians, but they rapidly changed to a pattern of their own, emulating rather Romanians, in terms of family reunification and their tendency to change from live-in to live-out care work, or to other jobs.

The question about years since migration clearly describe the historical evolution of migration to Italy from Eastern Europe: as mentioned in Section 2, first there was the inflows of Polish migrants, followed by Ukrainians, and then Romanians, followed by Moldovans.

Family migration also plays a different role in the groups: when we look at reasons for migration (Table 10), 67\% of Moldovan women came to Italy for labour purposes (in comparison to $77 \%$ of Ukrainians); and there are several Moldovan men who have applied for family reunification with wives who migrated earlier (44\%).

Unfortunately, we do not have this information for people from the European Union (and in particular for Poles and Romanians), since it is derived from residence permits data. However, findings from the LFS 2008 (2nd quarter) ${ }^{9}$ suggest that the share of Polish and Romanian women who migrated for work purpose is higher than among total migrants (respectively $51 \%$ and $44 \%$ ), even though lower compared to Moldovans and Ukrainians.

\section{Probability of employment and wages: a comparison}

In order to further explore the labour integration of Ukrainian and Moldovan migrant workers, we compared the chances of them being employed and their wage with three other groups of workers: natives, all migrants, and Poles and Romanians. The Probit of

Table 10 Rate of residence permits by reasons, 2010

\begin{tabular}{llccccl}
\hline & & Work & Family reasons (a) & Study purpose & Humanitarian (b) & Obs. \\
\hline Moldova & Men & 53.53 & 44.81 & 0.74 & 0.13 & 42,174 \\
& Women & 67.53 & 31.03 & 0.57 & 0.05 & 91,741 \\
\multirow{3}{*}{ Ukraine } & Men & 57.30 & 39.57 & 0.90 & 0.14 & 40,665 \\
& Women & 77.05 & 21.14 & 0.30 & 0.05 & 171,579 \\
\multirow{3}{*}{ Total immigrants } & Men & 59.17 & 34.97 & 1.43 & 2.65 & $1,728,945$ \\
& Women & 35.32 & 60.14 & 1.50 & 0.68 & $1,669,071$ \\
\hline
\end{tabular}

Source: Own elaborations based on Istat, Residence Permits (Home Office data).

Notes: (a) Including minors following an adult, even if they are present for different reasons. (b) Including asylum, asylum seekers, and humanitarian reasons.

The figures do not add up to 100.00 since some minors reasons are excluded from the table (religious, medical, other). 
the probability of employment is calculated with all the traditional controls: age, sex, level of education, region of residence, and years since migration. For the wage equation (OLS) we also include sector of employment.

Both Tables 11 and 12 show a larger differential towards natives that, however, declines when the reference group is more similar, as in the case of total migrants and in the case of Poles and Romanians.

Nevertheless, in all cases, Ukrainians and Moldovans show a higher probability of being employed than other communities (Table 11). When compared to Italians or other migrants, Romanian and Polish migrants are more likely to be employed, ceteris paribus. Being a woman has always a strong negative effect on participation in the labour market (specification (a) of Table 11). Given the different shares of women in our groups of interest, we also consider a specification without men.

Interestingly, when we consider the whole group (specification (a) of Table 11), the positive effect of being Ukrainian on the probability of being employed is significantly larger than the effect of being Romanian or Polish; on the contrary, the coefficients associated with Moldova is not statistically different from the others ${ }^{10}$.

However, if we take into consideration only women (specification (b) of Table 11), the differences between the groups decreases, even if both being Moldovan or Ukrainian still has a significantly larger effect than being Romanian. This difference disappears when we consider all the immigrants as a term of comparison, instead of Italians. Indeed, all female migrants from Eastern Europe show a much stronger attachment to the labour market then other female migrants, which more often enter Italy thanks to family reunification: ${ }^{11} 60 \%$ of total migrant women came to Italy for family reasons according to residence permits data - see Table 10 above; see also, for instance, Strozza et al. (2003).

Despite their higher probability of being employed, Ukrainian migrants are strongly penalized in terms of hourly wage (see Table 12$)^{12}$. In the case of comparison with Italians, being Ukrainian carries a significantly larger negative impact than being Moldovan or Romanian in the whole population (specification (a) of Table 12). In the case of women (specification (b) of Table 12) the negative impact is even larger, and significantly different from being Moldovan, Romanian or Polish.

The wage penalty disappears for all groups in the case of comparison with total migrants, with the notable exception of Ukrainian women.

Indeed, other researchers have shown that wages in home-care employment are significantly lower than in other sectors (Sarti 2011; Villosio and Bizzotto 2011; Piazzalunga 2013).

The duration of stay in the country of destination (years since migration) has a positive effect on the probability of being employed (Table 11). However, it has no impact on wages (Table 12), suggesting that once an individual is employed there, he has no chance of career or wage improvement. Indeed, several studies on the disadvantages of the national labour agreements in the domestic sector bring up this issue (Dell'Arringa and Pagani 2011; Sarti 2011; Piazzalunga 2013; Strøm et al. 2013).

To sum up, results suggest strongly that Ukrainian migrants, who are mainly female, are better educated but with poorly-paid jobs and that they tend to be older and to consider their migration as a temporary phase in their working life, during which they will maximise their total earnings. Regardless of the contiguity and the similarities with 
Table 11 Probability of being employed, working age population (15-64), 2011

\begin{tabular}{|c|c|c|c|c|c|c|}
\hline & \multicolumn{3}{|c|}{ Total (a) } & \multicolumn{3}{|c|}{ Women (b) } \\
\hline & $\begin{array}{l}\text { vs. } \\
\text { Italians }\end{array}$ & $\begin{array}{l}\text { vs. total } \\
\text { immigrants }\end{array}$ & $\begin{array}{l}\text { vs. Poland, } \\
\text { Romania }\end{array}$ & $\begin{array}{l}\text { vs. } \\
\text { Italians }\end{array}$ & $\begin{array}{l}\text { vs. total } \\
\text { immigrants }\end{array}$ & $\begin{array}{l}\text { vs. Poland, } \\
\text { Romania }\end{array}$ \\
\hline \multirow[t]{2}{*}{ Ukraine } & $0.52^{* * *}$ & $0.54^{* * *}$ & $0.20^{*}$ & $0.49^{* * *}$ & $0.54^{* * *}$ & $0.22^{*}$ \\
\hline & $(0.10)$ & $(0.10)$ & $(0.10)$ & $(0.11)$ & $(0.11)$ & $(0.12)$ \\
\hline \multirow[t]{2}{*}{ Moldova } & $0.26^{* *}$ & $0.44^{* * *}$ & 0.06 & $0.36^{* *}$ & $0.60^{* * *}$ & 0.20 \\
\hline & $(0.13)$ & $(0.11)$ & $(0.12)$ & $(0.15)$ & $(0.14)$ & $(0.14)$ \\
\hline \multirow[t]{2}{*}{ Poland } & $0.25^{* *}$ & $0.25^{* *}$ & & 0.21 & $0.33^{* *}$ & \\
\hline & $(0.12)$ & $(0.12)$ & & $(0.14)$ & $(0.14)$ & \\
\hline \multirow[t]{2}{*}{ Romania } & $0.18^{* * *}$ & $0.32^{* * *}$ & & 0.08 & $0.37^{* * *}$ & \\
\hline & $(0.05)$ & $(0.05)$ & & $(0.06)$ & $(0.07)$ & \\
\hline \multirow[t]{2}{*}{ Female } & $-0.71^{* * *}$ & $-0.87^{* * *}$ & $-0.69^{* * *}$ & & & \\
\hline & $(0.01)$ & $(0.04)$ & $(0.07)$ & & & \\
\hline \multicolumn{7}{|l|}{ Other control variables } \\
\hline \multirow[t]{2}{*}{$25-35$} & $1.24^{* * *}$ & $1.15^{* * *}$ & $1.13^{* * *}$ & $1.18^{* * *}$ & $0.94^{* * *}$ & $0.96^{* * *}$ \\
\hline & $(0.02)$ & $(0.07)$ & $(0.12)$ & $(0.03)$ & $(0.10)$ & $(0.16)$ \\
\hline \multirow[t]{2}{*}{$35-44$} & $1.62^{* * *}$ & $1.27^{* * *}$ & $1.27^{* * *}$ & $1.54^{* * *}$ & $1.06^{* * *}$ & $1.02^{* * *}$ \\
\hline & $(0.02)$ & $(0.07)$ & $(0.12)$ & $(0.03)$ & $(0.10)$ & $(0.16)$ \\
\hline \multirow[t]{2}{*}{$45-54$} & $1.60^{* * *}$ & $1.31^{* * *}$ & $1.32^{* * *}$ & $1.51^{* * *}$ & $1.24^{* * *}$ & $1.32^{* * *}$ \\
\hline & $(0.02)$ & $(0.08)$ & $(0.13)$ & $(0.03)$ & $(0.10)$ & $(0.16)$ \\
\hline \multirow[t]{2}{*}{$55-64$} & $0.65^{* * *}$ & $0.83^{* * *}$ & $0.97^{* * *}$ & $0.76^{* * *}$ & $0.87^{* * *}$ & $1.00^{* * *}$ \\
\hline & $(0.02)$ & $(0.10)$ & $(0.17)$ & $(0.03)$ & $(0.13)$ & $(0.20)$ \\
\hline \multirow[t]{2}{*}{ Married } & $0.08^{* * *}$ & $-0.46^{* * *}$ & $-0.43^{* * *}$ & $-0.23^{* * *}$ & $-0.78^{* * *}$ & $-0.57^{* * *}$ \\
\hline & $(0.01)$ & $(0.04)$ & $(0.08)$ & $(0.02)$ & $(0.06)$ & $(0.09)$ \\
\hline \multirow[t]{2}{*}{ North-east } & $0.08^{* * *}$ & -0.06 & -0.02 & $0.09^{* * *}$ & -0.10 & -0.08 \\
\hline & $(0.02)$ & $(0.05)$ & $(0.09)$ & $(0.02)$ & $(0.07)$ & $(0.11)$ \\
\hline \multirow[t]{2}{*}{ Centre } & $-0.11^{* * *}$ & -0.01 & -0.00 & $-0.13^{* * *}$ & $-0.15^{* *}$ & -0.10 \\
\hline & $(0.02)$ & $(0.05)$ & $(0.09)$ & $(0.02)$ & $(0.07)$ & $(0.11)$ \\
\hline \multirow[t]{2}{*}{ South } & $-0.55^{* * *}$ & $-0.21^{* * *}$ & $-0.36^{* * *}$ & $-0.66^{* * *}$ & $-0.29^{* * *}$ & $-0.41^{* * *}$ \\
\hline & $(0.02)$ & $(0.06)$ & $(0.11)$ & $(0.02)$ & $(0.09)$ & $(0.13)$ \\
\hline \multirow[t]{2}{*}{ Islands } & $-0.49^{* * *}$ & -0.00 & -0.24 & $-0.60^{* * *}$ & -0.17 & $-0.55^{* * *}$ \\
\hline & $(0.02)$ & $(0.09)$ & $(0.16)$ & $(0.03)$ & $(0.14)$ & $(0.21)$ \\
\hline \multirow[t]{2}{*}{ Lower sec. } & $0.44^{* * *}$ & 0.10 & 0.13 & $0.50^{* * *}$ & 0.12 & 0.11 \\
\hline & $(0.02)$ & $(0.06)$ & $(0.13)$ & $(0.03)$ & $(0.09)$ & $(0.16)$ \\
\hline \multirow[t]{2}{*}{ Upper sec. } & $0.95^{* * *}$ & $0.30^{* * *}$ & $0.35^{* * *}$ & $1.11^{* * *}$ & $0.38^{* * *}$ & $0.31^{* *}$ \\
\hline & $(0.02)$ & $(0.06)$ & $(0.12)$ & $(0.03)$ & $(0.09)$ & $(0.15)$ \\
\hline \multirow[t]{2}{*}{ Tertiary } & $1.23^{* * *}$ & $0.40^{* * *}$ & $0.50^{* * *}$ & $1.44^{* * *}$ & $0.47^{* * *}$ & $0.45^{* *}$ \\
\hline & $(0.03)$ & $(0.08)$ & $(0.16)$ & $(0.04)$ & $(0.11)$ & $(0.19)$ \\
\hline \multirow[t]{2}{*}{ Years since migration } & & $0.06^{* * *}$ & 0.03 & & $0.07^{* * *}$ & 0.04 \\
\hline & & $(0.01)$ & $(0.03)$ & & $(0.01)$ & $(0.03)$ \\
\hline \multirow[t]{2}{*}{ Years since migration sq. } & & $-0.00^{* * *}$ & -0.00 & & $-0.00^{* * *}$ & -0.00 \\
\hline & & $(0.00)$ & $(0.00)$ & & $(0.00)$ & $(0.00)$ \\
\hline \multirow[t]{2}{*}{ Constant } & $-1.10^{* * *}$ & $-0.60^{* * *}$ & -0.21 & $-1.68^{* * *}$ & $-1.22^{* * *}$ & $-0.66^{* * *}$ \\
\hline & $(0.03)$ & $(0.10)$ & $(0.19)$ & $(0.04)$ & $(0.14)$ & $(0.23)$ \\
\hline Observations & 94,139 & 8,185 & 2,724 & 48,439 & 4,435 & 1,689 \\
\hline
\end{tabular}

Standard errors in parenthesis. ${ }^{* *} \mathrm{p}<0.01,{ }^{* *} \mathrm{p}<0.05,{ }^{*} \mathrm{p}<0.1$. t13:48.

Reference group is: 15-24 years old, non-married, North-west, Primary education and below. 
Table 12 Wage equation, working age population (15-64), 2011

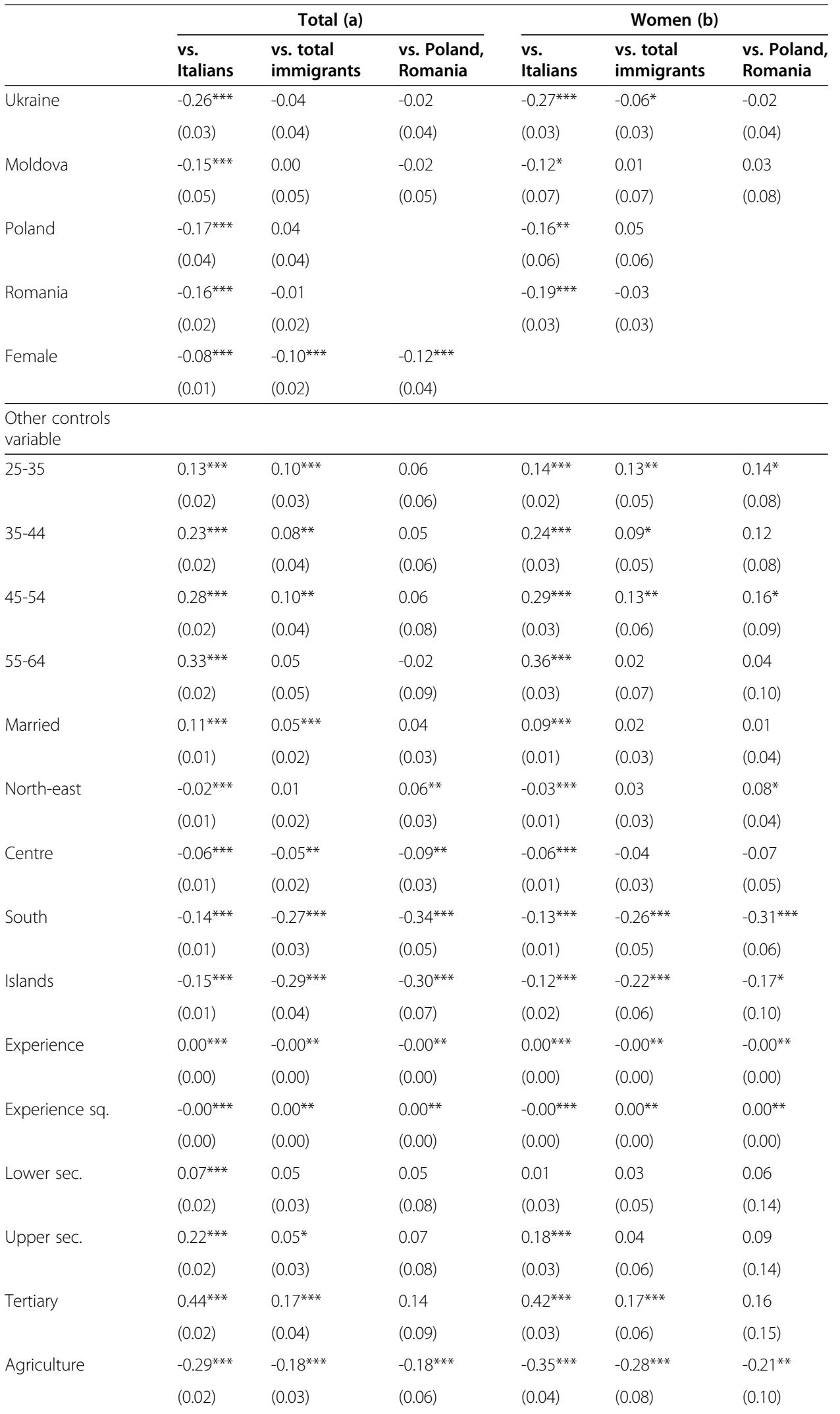


Table 12 Wage equation, working age population (15-64), 2011 (Continued)

\begin{tabular}{|c|c|c|c|c|c|c|}
\hline \multirow[t]{2}{*}{ Construction } & $-0.05^{* * *}$ & -0.01 & 0.00 & 0.04 & $-0.42^{* *}$ & $-0.69^{* * *}$ \\
\hline & $(0.01)$ & $(0.02)$ & $(0.04)$ & $(0.03)$ & $(0.19)$ & $(0.22)$ \\
\hline \multirow[t]{2}{*}{ Commerce } & $-0.04^{* * *}$ & -0.01 & 0.06 & $-0.04^{* * *}$ & -0.05 & 0.02 \\
\hline & $(0.01)$ & $(0.02)$ & $(0.04)$ & $(0.01)$ & $(0.05)$ & $(0.06)$ \\
\hline \multirow[t]{2}{*}{ Business } & -0.01 & $-0.09^{* * *}$ & -0.03 & -0.02 & $-0.10^{* *}$ & -0.00 \\
\hline & $(0.01)$ & $(0.03)$ & $(0.06)$ & $(0.01)$ & $(0.05)$ & $(0.06)$ \\
\hline \multirow[t]{2}{*}{ Public and social } & $0.12^{* * *}$ & $0.11^{* * *}$ & $0.11^{* *}$ & $0.14^{* * *}$ & $0.09^{*}$ & 0.08 \\
\hline & $(0.01)$ & $(0.04)$ & $(0.05)$ & $(0.01)$ & $(0.05)$ & $(0.05)$ \\
\hline \multirow[t]{2}{*}{ Social and families } & $-0.11^{* * *}$ & $-0.08^{* * *}$ & -0.05 & $-0.13^{* * *}$ & $-0.10^{* *}$ & $-0.09 *$ \\
\hline & $(0.01)$ & $(0.03)$ & $(0.05)$ & $(0.02)$ & $(0.04)$ & $(0.05)$ \\
\hline \multirow{2}{*}{$\begin{array}{l}\text { Years since } \\
\text { migration }\end{array}$} & & 0.01 & -0.00 & & -0.00 & -0.01 \\
\hline & & $(0.00)$ & $(0.01)$ & & $(0.01)$ & $(0.02)$ \\
\hline \multirow{2}{*}{$\begin{array}{l}\text { Years since } \\
\text { migration sq. }\end{array}$} & & 0.00 & 0.00 & & $0.00^{*}$ & 0.00 \\
\hline & & $(0.00)$ & $(0.00)$ & & $(0.00)$ & $(0.00)$ \\
\hline \multirow[t]{2}{*}{ Constant } & $1.64^{* * *}$ & $1.74^{* * *}$ & $1.82^{* * *}$ & $1.59^{* * *}$ & $1.73^{* * *}$ & $1.67^{* * *}$ \\
\hline & $(0.02)$ & $(0.05)$ & $(0.11)$ & $(0.04)$ & $(0.09)$ & $(0.17)$ \\
\hline Observations & 36,918 & 4,190 & 1640 & 16,906 & 1,861 & 959 \\
\hline
\end{tabular}

Standard errors in parenthesis. ${ }^{* *} p<0.01,{ }^{* *} p<0.05,{ }^{*} p<0.1$.

Reference categories are: 15-24 years old, non-married, north-west, primary education and below, industry.

Polish migration, migration from Ukraine has peculiar features in terms of labour market outcomes.

Conversely, the Moldovan community, which includes both men and women, is slightly less well educated. However, it is less penalised in wage terms, and it tends to settle and see families reunified.

Ukrainian and Moldovan women, even though they both work in household services, are employed with different hiring modalities. They both begin in the more demanding type of employment, living with their employer. Afterwards, though, they tend to follow two different migration trajectories: Ukrainians tend to remain in the demanding family care sector, while Moldovans are present in the (slightly) less demanding job of cleaning and domestic work and are more focussed on family reunification.

With the results from this paper we are not able to understand if the composition of the labour supply (age, gender, education, reason to migrate) has conditioned the migration trajectory; or whether the demand for jobs (sector, skill) has conditioned the specific type of labour supply. Both groups of migrants come from neighbouring countries. But the different Moldovan and Ukrainian migration projects should be linked to the different socio-economic conditions in their countries of origin and the difference in employment opportunities at home for young and/or more mature women as well as for men. It is enough for present purposes to note that the income per capita - which provides an indicator of wealth - is 20 per cent of the EU15 average in Moldova versus 35 per cent in Ukraine ${ }^{13}$. Therefore, while Moldovans have a permanent migration project towards Western Europe, Ukrainians are mainly engaged in temporary migration given that their country has better potential for economic development and recovery. Moldovan men are mainly employed in construction and commerce, and have 
temporary migration plans. However, instead, they have the highest per cent migration for family reasons and they follow the Romanians model, which is also well established in the construction and commerce sector.

\section{Discussion and conclusions}

In our paper, we started with the acknowledgement that Italy has an increasing need for new migrant population, mainly due to its ageing and shrinking native population. We have also identified temporary migration as the best option in this scenario, due to the anti-immigration feelings in the country and the consequent difficulties of a more open migration policy. Given their geographical proximity and relatively wealthy socio-economic conditions, migrants from the Eastern Partnership countries are, we suggested, the best candidates to fill this void in the Italian labour market.

We then illustrated the main features of the migration flows from EaP countries, by looking at the differences and similarities amongst the presence in Italy of EaP nationals in general, and of Ukrainians and Moldovans in particular. In so doing, we paid particular attention to the condition of women, given the feminized character of these two groups. Domestic work and care work is, indeed, a crucial sector of employment for these migrants.

Migrants from Poland and Romania have served as a useful point of comparison. Migration from these two countries towards Italy is at the heart of the dynamics taking place in domestic and care work.

The paper analyses data related to skill mismatch, distribution in working sectors, length of stay and the age of the above-mentioned groups. We also looked at the motivation for their residence permits, their family and living situation, and, crucially, their intentions towards stabilization in Italy or their return to their country of origin. Last, we have analysed the labour performance of these groups by comparing wages and the probability of being employed for Moldovans and Ukrainians with Italians, all migrants, and Poles and Romanians.

The different characteristics of the immigrant inflows in terms of gender, age, education, reason for migration and labour market performance, show the existence of two different migration strategies, with family reunification and a higher probability of settlement in the case of Moldovans and temporary migration for Ukrainians. Probably, the different migration projects are influenced by employment probability and economic conditions at home.

In the context of the current economic crisis the migration project of Ukrainian migrants - mainly women with temporary migration in the family care sector - seem more successful and sustainable than the Moldovan equivalent. While, until 2007, the number of Italian women employed in family services was scarce, it increased during the crisis, compensating for their loss of jobs or for those of their husbands (Ismu 2011b). That growth generated a space for possible competition between low-skilled Italian women and foreign women in the labour market. However, Italian women did not enter into the more demanding "live-in" care sector, but stuck rather to the more flexible cleaning and domestic sector. Hence, while Ukrainian women are predominant in a sector where Italians will remain absent, Moldovan and low-skilled Italians women could partially substitute each other, something that might lead to tension. In addition, 
the construction sector experienced increased unemployment, which touched both natives and Moldovan and Romanian male workers.

However, if the recession is increasing the instability of the more permanent migration project of Moldovans, the aging and the shrinking of the Italian population is creating in the short run a demand for temporary migrants but in the medium run a demand for permanent migrants and for their integration. The migration policy through bilateral agreements and the Mobility Partnership Agreement signed by the Moldova ${ }^{14}$ with the European Union and the negotiated visa free regime for Georgia, Ukraine, Moldova or a visa facilitation regime for Armenia and Azerbaijan can favour and protect both temporary and permanent flows of migrants.

\section{Endnotes}

${ }^{1}$ See Gavosto et al. 1999, Del Boca and Venturini 2005, Venturini and Villosio 2006, D’Amuri and Pinotti 2010, Staffolani and Valentini 2010, Tognetti Borgogna 2011.

${ }^{2} \mathrm{Cfr}$. http://www.demo.istat.it/altridati/noncomunitari/index.html (only Italian).

${ }^{3}$ Censis: www.censis.it.

${ }^{4}$ Ismu Foundation: www.ismu.org.

${ }^{5}$ ORIM (Osservatorio Regionale per l'Integrazione e la Multietnicità): http://www. orimregionelombardia.it/.

${ }^{6}$ See Marchetti et al. (2013) for a description of the legal framework for migration to Italy.

${ }^{7}$ According to Duszczyk et al. (2013), Poland is facilitating the employment of migrants from third countries. Among other measures, foreigners from some nonEuropean countries are allowed to work in the country for up to 6 months per year without the obligation of a work permit. In particular, this measure also concerns citizens from Belarus, Georgia Moldova, Russia and Ukraine.

${ }^{8}$ While figures for most communities are contained in Ismu (2011a), findings for Moldovan migrants were provided upon request, and can be found in Marchetti et al. (2013). We do not have information for Poland.

${ }^{9}$ In 2008, 2nd quarter, the LFS contained an ad hoc module for foreign nationals; among other questions, it asked "For which main reasons did you come to Italy?". However, the information from the residence permits is official.

${ }^{10}$ For both the probability of being employed and the wage equation, we test if the coefficients associated to the country of origin are statistically different among themselves. We decided not to include the results in the table, for the sake of synthesis. However, results are available from the authors upon request.

${ }^{11}$ With the relevant exception of women from the Philippines and from South America.

${ }^{12}$ For the assimilation of migrants, see Venturini and Villosio (2008), Strøm et al. (2013).

${ }^{13}$ According to the World Bank World Development Indicators, gross domestic product (GDP) in purchasing power parity in 2010 was 7,700 USD in Ukraine and 2,800 USD in Moldova, the worst off with respect to other EaP countries. In terms of comparison, it was 17,625 in Poland (ETF 2011, p. 10).

${ }^{14}$ See the migration profile on Moldova by the Migration Policy Centre (2013): http:// www.migrationpolicycentre.eu/docs/migration_profiles/Moldova.pdf. 


\section{Competing interest}

The IZA Journal of European Labor Studies is committed to the IZA Guiding Principles of Research Integrity. The authors declare that they have observed these principles.

\section{Acknowledgement}

This study was conducted under the project entitled "Costs and Benefits of Labour Mobility between the EU and the Eastern Partnership Countries" project for the European Commission (Contract No. 2011/270-312, tender procedure EuropeAid/130215/C/SER/Multi). The European Commission retains ownership of the materials contained herein. Responsible editor: Martin Kahanec

\section{Author details}

${ }^{1}$ EUI-RSCAS, Via delle Fontanelle, 19, 50014 San Domenico di Fiesole, FI, Italy. ${ }^{2}$ Department of Economics and Statistics "Cognetti de Martiis", University of Turin and CHILD-Collegio Carlo Alberto, via Real Collegio, 30, 10024 Moncalieri, TO, Italy. ${ }^{3}$ Department of Economics, MPC, European University Institute, University of Turin, IZA and CHILD, Lungo Dora Siena 100, 10153 Torino, Italy.

Received: 6 November 2013 Accepted: 18 January 2014

Published: 24 Apr 2014

\section{References}

Ambrosini M, Beccalli B (2009) Uomini in Lavori da Donne: il Lavoro Domestico Maschile. In: Catanzaro R, Colombo A (eds) Badanti and Co. II Lavoro Domestico Straniero in Italia. II Mulino, Bologna

Barone G, Mocetti S (2012) With a little help from abroad: the effect of low-skilled immigration on the female labour supply. Labour Econ 18(5):664-675

Bentivogli F, Carfagna M, Pittau F (2004) L'incidenza dell'Est Europa in Italia Dopo la Regolarizzazione del 2002. In: Olivieri F, Pittau F, Ricci A (eds) Europa. Allargamento a Est e immigrazione. Idos, Roma

Censis (2010) Dare Casa Alla Sicurezza. Rischi e Prevenzione per i Lavoratori Domestici. Censis, Roma

D'Amuri F, Pinotti P (2010) Immigration and natives' Labor Market Outcomes: Evidence from Italy, Mimeo. Bank of Italy, Roma

Del Boca D, Venturini A (2005) Italian Migration. In: Zimmermann KF (ed) European Migration. What do we Know? Oxford UP, Oxford

Del Boca D, Venturini A (2014) Migration in Italy is Backing the old age Welfare. In: Kahanec M, Zimmermann KF (eds) Migration and EU Labor Markets After the Second Enlargement. Springer, Berlin

Dell'Arringa C, Pagani L (2011) Labour market assimilation and over-education: the case of immigrant workers in Italy. Economia Polit 2:219-240

Duszczyk M, Góra M, Kaczmarczyk P (2013) Costs and Benefits of Labour Mobility Between the EU and the Eastern Partnership Countries. Country Report, Poland, EuropeAid/130215/C/SER/Multi

Esping-Andersen G (1990) The Three Worlds of Welfare Capitalism. Polity Press, Cambridge

ETF (2011) Labour Markets and Employability: Trends and Challenges in Armenia, Azerbaijan, Belarus, Georgia. Moldova and Ukraine. EU office, Luxembourg

European Commission (2012) The 2012 Aging Report. European Economy n. 2/2012, Brussels

Eurostat (2013) Old-age Dependency Ratio. http://epp.eurostat.ec.europa.eu/tgm/table.do?tab=table\&init=1\&plugin=1\&language $=$ en\&pcode=tsdde510. Accessed 30 Sept 2013

Ferrera M, Rhodes M (2000) Recasting European Welfare States. Frank Cass, London

Gavosto A, Venturini A, Villosio C (1999) Do immigrants compete with natives? Labour 13(3):603-621

Ismu (2011a) Decimo Rapporto Sugli Immigrati in Lombardia. Regione Lombardia, Milano

Ismu (2011b) Sedicesimo Rapporto Sulle Migrazioni 2010. FrancoAngeli, Milano

Istat (2013) Employment and Unemployment. http://www.istat.it/en/archive/98035. Accessed 30 Sept 2013

Marchetti S, Venturini A (2013) Mothers and grandmothers on the move: labour mobility and the household strategies of Moldovan and Ukrainian migrant women in Italy. Int Migr, doi: 10.1111/imig.12131

Marchetti S, Piazzalunga D, Venturini A (2013) Costs and Benefits of Labour Mobility Between the EU and the Eastern Partnership Countries. Country Report, Italy, IZA Discussion Paper n. 7635

Migration Policy Centre (2013) Migration Profile Moldova. http://www.migrationpolicycentre.eu/docs/ migration_profiles/Moldova.pdf

Pasquinelli S, Rusmini G (2013) Badare non Basta. II Lavoro di Cura: Attori, Progetti, Politiche. Ediesse, Roma

Piazzalunga D (2013) Is There a Double-Negative Effect? Gender and Ethnic Wage Differentials. CHILD, Torino, working paper n. 11/2013. http://www.child.carloalberto.org/images/documenti/child11_2013.pdf

Romiti A, Rossi C (2011) Should we Retire Earlier in Order to Look After our Parents? The Role of Immigrants. CeRP, Moncalieri (TO), working paper n. 124/11. http://www.cerp.carloalberto.org/it/pubblicazioni/working-papers/845should-we-retire-earlier-in-order-to-look-after-our-parents-the-role-of-immigrants

Sarti R (2011) Lavoro Domestico e di Cura: Quali Diritti? Ediesse, Roma

Staffolani S, Valentini E (2010) Does immigration raise blue and white collar wages of natives? The case of Italy. Labour 24(3):295-310

Strøm S, Venturini A, Villosio C (2013) Wage Assimilation: Migrants Versus Natives, Internal Migrants Versus Foreign Migrants, EUI, San Domenico di Fiesole (FI), working paper RSCAS 2013/30, http://www.migrationpolicycentre.eu/ docs/RSCAS-2013-30.pdf

Strozza S, Gallo G, Grillo F (2003) Gender and the Labour Market Among Immigrants in Some Italian Areas: The Case of Moroccans, Former Yugoslavians and Poles. In: Garcia B, Anker R, Pinnelli A (eds) Women in the Labour Market in Changing Economies: Demographic Issues. Oxford UP, Oxford

Tognetti Bordogna M (2011) Le Badanti: Accesso e uso del Welfare Sanitario per se e per il Badato. In: Caponio T, Giordano F, Manetti B, Ricaldone L (eds) World Wide Women. Globalizzazione, Generi, Linguaggi, Vol. 3rd edn. CIRSDe, Torino 
Transatlantic Trends (2011) Transatlantic Trends: Immigration. Key Findings 2011. German Marshall Fund of the United States, Bradley Foundation, Compagnia di San Paolo, Barrow Cadbury Trust. http://trends.gmfus.org/immigration/ key-findings/

Venturini A, Villosio C (2006) Labour market effects of immigration into Italy: an empirical analysis. Int Labour Rev 145(1-2):91-118

Venturini A, Villosio C (2008) Assimilation of migrants in recent immigration countries: the Italian experience. Oxford Rev Econ Pol 24(3):518-542

Vianello FA (2009) Migrando Sole, Legami Transazionali tra Ucraina ed Italia. Franco Angeli, Milano

Villosio C, Bizzotto G (2011) Once there were wives and daughters, now there are badanti. Walqing Social Partnership Series 2011:14

Zimmermann KF, Biavaschi C (2013) Costs and Benefits of Labour Mobility Between the EU and the Eastern Partnership Countries. Country Report, Germany, EuropeAid/130215/C/SER/Multi

10.1186/2193-9012-3-8

Cite this article as: Marchetti et al:: Does Italy represent an opportunity for temporary migrants from the eastern partnership countries? IZA Journal of European Labor Studies 2014, 3:8

Submit your manuscript to a SpringerOpen ${ }^{\circ}$ journal and benefit from:

- Convenient online submission

- Rigorous peer review

- Immediate publication on acceptance

- Open access: articles freely available online

- High visibility within the field

- Retaining the copyright to your article

Submit your next manuscript at $>$ springeropen.com 